\title{
Viral Respiratory Tract Infections After Hematopoetic Stem Cell Transplantation in Pediatric Patients
}

\author{
Kök Hücre Aktarımı Yapılan Çocuklarda Virüs Nedenli \\ Solunum Yolu Enfeksiyonları
}

\author{
İmran Sağlık', Dilek Çolak \\ ' Department of Medical Microbiology, Division of Virology, Akdeniz University School of Medicine, Antalya, Turkey
}

\section{Abstract}

Viral respiratory tract infections (VRTI) after hematopoietic stem cell/ bone marrow transplantation (HSCT) are associated with severe morbidity and mortality. Although protective measures have been increased from VRTI for HSCT patients in recent years, these infections are still a serious problem.

Treatment regimens which applied for preparation of HSCT and immunosuppressive treatments, used to prevent graft versus host disease (GVHD), especially in patients who underwent allogeneic stem cell transplantation, can lead to suppression of the patients immune system and become more sensitive to the respiratory viral infectious agents. Early diagnosis and treatment are very important because they can prevent serious complications which can cause of these infections and ensure the infection control measures. Nucleic acid-based tests have begun to use widely in recent years, have provided rapid, accurate and reliable diagnosis of respiratory viral infectious agents. In particular, with the introduction of the multiplex molecular assays that able to simultaneously detect many pathogens, has facilitated the diagnosis of some pathogens which couldn't detected by conventional methods previously. In this article, VRTI, and viral respiratory infections agents encountered in HSCT performed children are presented as a literature review.

Keywords: Hematopoietic cell transplantation, viral respiratory infections, respiratory virus, pediatric
Özet

Hematopoietik kök hücre/kemik iliği aktarımı (transplantasyonu) (HKHA) yapılan hastalarda virüs nedenli solunum yolu enfeksiyonları (VSYE) önemli bir hastalanım ve ölüm nedenidir. Son yıllarda konuyla ilgili farkındalığın artmasıyla birlikte hastaları bu enfeksiyonlardan koruyucu önlemler artırılmıştır. Ancak HKHA yapılan hastalarda VSYE sorun olmayı sürdürmektedir. HKHA'ya hazırlık için ve özellikle allojenik kök hücre aktarımı (AKHA) yapılan hastalarda graft versus host (konağa karşı yama) hastalığını (GVHH) önlemek için uygulanan immün baskılayıcı tedaviler hastaları virüs nedenli solunum yolu enfeksiyon etkenlerine daha duyarlı duruma getirmektedir. Erken tanı ve tedavi, bu enfeksiyonların yol açabileceği önemli art sorunları önleyebileceği ve enfeksiyon denetim önlemlerinin alınmasını sağlayabileceği için çok önemlidir. Son yıllarda tanıda yaygın olarak kullanılmaya başlanan çekirdek asidi testleri VSYE etkenlerinin zamanında, doğru ve güvenilir tanısını sağlamıştır. Özellikle çok sayıda etkeni aynı anda saptayabilen (multipleks) testlerin kullanılmaya başlanması geleneksel yöntemlerle saptanması güç olan etkenlerin tanısını kolaylaştırmıştır. Bu yazıda HKHA yapılan çocuklarda karşılaşılan VSYE ve etkenleri literatür gözden geçirilerek bir derleme biçiminde sunulmuştur.

Anahtar kelimeler: Hematopoietik hücre aktarımı, virüs nedenli solunum yolu enfeksiyonu, solunum yolu virüsleri, çocuklar 


\section{Introduction}

Hematopoetic stem cell/bone marrow transplantation (HSCT) is a successfully practiced method in the treatment of many diseases such as hematologic malignant disease, immunodeficiency, hemoglobinopathy, bone marrow deficiency and congenital metabolic diseases in pediatric patients. HSCT is a process where the entire or part of the bone marrow of the patient is drained and the healthy stem cells are placed and multiplied. Stem cells used for transplantation are obtained from peripheral blood, bone marrow or the umbilical cord. The term "allogenic stem cell transplantation" (ASCT) is used if the patient is given stem cells from a healthy individual and the term "autologous stem cell transplantation" (ASCT) is used if the patient is re-given his/her stem cells. The disease or the state of the disease is considered for deciding upon which transplantation to be performed (1).

Prior to HSCT, treatment-chemotherapy, total body radiation, immunosuppressant drugs- named as "preparation approach" given specifically to the patient and the disease in order to monitor the disease or facilitate the placement of the given stem cells causes pancytopenia and suppression of the immune system, and the patients become more vulnerable not just to many infection agents but also to viral respiratory tract infection agents. Besides, immunosuppressant treatment implemented to prevent graft versus host disease (GVHD) in HSCT patients leads to acquired immunodeficiency and increases the risk of infection. In the development of viral respiratory tract infection (VRTI), HSCT (especially from an unrelated donor), umbilical cord blood transplantation, acute or chronic GVHD development, lymphopenia, insufficient engraftment, CMV seropositivity, and the male gender are among the risk factors (25). It has been reported that VRTI frequency and complications in the first 100 days after transplantation are higher $(4,6)$.

It has been determined in studies that rats with deteriorated flora are more susceptible to influenza A virus than normal rats, and also increased influenza virus titers and pathogenesis have been observed in rats treated with antibiotics when compared to normal rats (7-9). Having found that increased viral reproduction and disease in rats treated with antibiotics is connected with IgG and IgM antibody response and reduced $\mathrm{T}$ cell unique to the virus $\left(\mathrm{CD}^{+}\right)$makes us think that there is insufficient adaptive immune response in rats with weakened microbiota (10). Since high-dose antibiotic treatment given to prevent bacterial and fungal infections deteriorates normal respiratory tract flora in HSCT patients, particularly in severe neutropenia phase, the settling of the viruses gets easier and the severity of the infection developed can also be affected. The progress of the infection to the lower respiratory tract (28.0\%-64.0\%) can be much easier and deadly in these patients (3). Furthermore, VRTI can lead up to secondary bacterial and fungal infections.
VRTI rates have been slightly higher in ASCT patients $6.5 \%$ $21.0 \%$ ) when compared to autologous stem cell transplantation patients (6.2\%-13.0\%). Similarly, the frequency of lower respiratory tract infection (LRTI) has been found higher in ASCT patients (3.5\%) in comparison to autologous stem cell transplantation patients (1.7\%). Mortality rate in HSCT patients after VRTI has been reported as $9.4 \%-10.0 \% \quad(3,4,11-13)$. It should be taken into consideration that these rates can differ slightly depending upon the method of diagnosis used and also that more than one factor can have a cumulative effect on mortality rate $(3,4,12)$.

Respiratory syncytial virus (RSV), influenza A and B viruses, rhinovirus, parainfluenza virus (PIV), adenovirus, coronavirus, and metapneumovirus in children have been reported as respiratory tract infection factors. The prevalence of infections, as in the normal population, can change seasonally; RSV and influenza virus infections are seen in winter, PIV infections in autumn and summer, and adenovirus infections can be seen throughout the year $(2,4,12)$.

\section{Clinical Picture}

Upper respiratory tract of most patients with suppressed immune system is affected and clinical findings such as cough (most common), nasal flow, fever, nasal blockage, sinusitis, headache, middle ear infection, sore throat, croup, wheeze, fatigue, malaise, muscle pain can manifest. Bronchitis, bronchiolitis, and pneumonia can develop in patients whose lower respiratory tract is affected due to widespread infection. More severe findings like hypoxia and respiratory distress can be seen in these patients and changes can be detected in radiological examinations $(2,3)$. It has been reported that clinical findings can progress more severely and hospital stay can be prolonged in patients in whom more than one virus is detected (14). The severity of clinical findings has been found directly connected to immunosuppression (15).

\section{Diagnosis}

Since all viral factors can lead to similar clinical pictures, specific diagnosis can only be reached by laboratory examinations. Early diagnosis and treatment in immunosuppressed patients is of vital importance since it can prevent significant complications these infections can lead to. Samples like nasopharynx aspirates, eluate, and trachea-alveol irrigation are beneficial; however, implementation is relatively difficult. Flexible flocked swabs that have entered into application in recent years provide convenience and ease in taking samples and handling them and have been successfully and quite commonly used in isolating respiratory tract viruses $(16,17)$.

Even though direct fluorescent antigen (DFA) testing is implemented in many laboratories due to it being quick and a relatively cheap method, its sensitivity (38\%-93\%) and specifity 
(65\%-100\%) vary $(16,18,19)$. Experience is needed in the evaluation of the test and the number of viruses to obtain antigen for the test is limited (21). Quick antigen tests are cheap, easily-implemented and do not necessitate technical equipment and produce results in about one hour, but their sensitivity (60\%-75\%) and specifity (50\%-100\%) also vary. It has been determined that they are relatively more sensitive in patients with high virus titer, like in children. There are FDA-approved tests for influenza A and B viruses and RSV $(18,20,21)$. Quick antigen tests have been found useful in emergency services where patient traffic is high and plenty (22). Despite being implemented by many centers due to their superiority, it should not be forgotten that negative results of DFA and quick antigen tests need to be confirmed by another method $(16,18)$. Viral culture in the diagnosis of factors of viral respiratory tract infection is the golden standard. However, although time span for results has decreased to 24-72 hours with methods like shel vial or R-mix , they can be implemented in a limited number of centers since they require technical equipment $(16,19)$. Nucleic acid test possessed the highest sensitivity among all methods. In recent years, the development of multiplex tests with which a wide range of factors can be searched quickly has ensured to easily detect infections with multiple factors and are preferred by many centers. There are different methods (real-time PZT, multiplex PZT, MALDI-TOF, luminex technology, arrays) intended for the detection of nucleic acids with high sensitivity and specifity rates that can give results in hours and can be highly useful in the diagnosis of respiratory tract infections in HSCT patients $(4,11,21,23,24)$. Viruses that were previously not reported as factors have been determined with the implementation of these tests and the diagnosis of multiple viral infections has got easier (25). It has been confirmed that multiple viral infections are encountered more frequently $(12 \%-23 \%)$ in pediatric patients $(14,26)$.

\section{RSV}

RSV is the most important VRTI factor defined in pediatric patients and is seen at a rate of $14-28 \%(2-4,11,13)$. Mortality rate of RSV infection in immunosuppressed children has been reported as $10.0-40.0 \%(4,27)$.

RSV infections are usually seen between December and March. They lead to upper and lower respiratory tract infections without complications and are considered as a common cause for bronchitis, bronchiolitis and pneumonia $(14,20,26)$. Besides, it is the most frequently detected virus (co-occurrence of rhinovirus and RSV, adenovirus and RSV) in multiple viral infections $(14,26)$.

Average time period of the symptoms in children without any immune problems is 4-10 days. Prolonged wheeze, fever and cough can be observed when compared to other viral factors. The progression of the disease to the lower respiratory tract in HSCT patients may result in high mortality rates (9\%-29\%)
$(2,15,25,28)$. The infection is generally limited to the respiratory system; however, there are cases reporting heart and liver involvement (29). Moreover, RSV viremia can be encountered in adult HSCT patients with lower respiratory tract infection associated with RSV in whom mechanical ventilation is particularly implemented, and viremia has been found to correlate with the mortality rate (15).

Rate of contamination is high in hospitals (30\%-40\%) and RSV can cause outbreaks in immunosuppressed patients receiving in-patient treatment $(2,13,25,30)$. Contamination takes place through contact with infected patients or objects that are contaminated or healthcare workers.

If supportive care in RSV infections can be provided in especially patients at risk for lower respiratory tract infections, treatment against the virus is recommended. Ribavirin, an artificial analogous nucleoside, is the most commonly used anti-viral drug that can be used orally, inhaled and through venous blood vessels. Ribavirin treatment, which can be used on its own or with immunomodulating drugs, has been reported to be able to prevent the progression of the infection to lower respiratory tract (31). It has been reported that ribavirin which is inhaled in RSV infections decreases mechanical ventilation, length of hospital stay and recurring wheezing attacks and is more efficient in treatment, and besides, the implementation of ribavirin through other modes is also beneficial in treatment $(2,5,15,28,31)$. However, data regarding this field is based on case reports, reviews, retrospective or un-controlled studies. The use of the drug is limited due to the fact that there are unwanted effects including hemolysis, leucopenia and hyperbilirubinemia of systemic ribavirin and obstructive respiratory distress of inhaled ribavirin and also due to the insufficiency of controlled clinical studies regarding the efficiency of the drug (28). There is a need for large-scale, prospective and controlled studies regarding the benefit of antiviral treatment.

Immunomodulating drugs are also recommended in treatment. Passive immune protection can be implemented with immunoglobulin (IVIG) through venous blood vessels so as to prevent the complications caused by the infection. Palivizumab (RSV mono-clonal antibody) implementation has been found more useful in patients with hypogammaglobulinemia than passive immune protection with IVIG, and it was recommended in international guidelines in 2009 (1). Furthermore, close follow-up of patients in risk groups (early age, neutropenia, lymphocytopenia, GVHD, myelo-ablative treatment, use of corticosteroids, right after transplantation or pre-engraftment period) can be useful in the prevention of the infection and its complications $(5,28,31)$.

\section{Parainfluenza virus}

Along with encountering the virus more frequently in autumn and summer, the frequency and mortality rate of the virus vary respectively as $6.2 \%-22 \%$ and $10.5 \%-13 \%$. PIV type 
3 is seen more commonly as a factor among the subtypes of the virus $(2,4,11,32)$. Total body radiation and ASCT have been found connected to symptomatic PIV infection. Although similar clinical findings are observed with normal children, the infection starting from the upper respiratory tract may progress into lower respiratory tract infections including croup, laryngotracheite and pneumonia (39\%) and give rise to clinical pictures that necessitate significant respiratory support (32). Certain drugs like ribavirin have been tested in treatment; however, absolute data regarding its usefulness have not been obtained $(2,3)$. Treatment and IVIG use aimed at preventing secondary bacterial infections in patients with lower tract infections like pneumonia is recommended (31).

\section{Influenza virus}

Influenza viruses are detected at a rate of $4.5-22 \%$ and can lead to infections with high mortality rates $(2-4,11)$. Mortality rate can increase with the addition of bacteria to the process (25). These are viruses that are more commonly seen in winter and that can lead to epidemics. It can progress with typical cough, muscle and joint pain, headache and high fever that are observed in influenza infections clinically. While influenza type $A$ is associated with interstitial pneumonia and high mortality rates, influenza type $B$ is encountered relatively less frequently and progresses more moderately. Prolonged virus scatter can be seen in HSCT patients who are asymptomatic or show few symptoms. This condition can lead to new cases or epidemics and to the emergence of diversities resistant to antiviral drug use $(17,21)$.

M2 prophylactics (amantadine and rimantadine) are used in treatment in certain centers; however, side effects and increasing resistance rates limit their use. Neuraminidase prophylactic drugs (oseltamivir) are used widely in antiviral treatment. It is known that it is more effective when treatment is started in the first 24 hours of the infection. On the other hand, it has been reported that it can be useful in patients whose treatment started late. Although combined antiviral treatments become prominent in the existence of drug resistance, many centers remain insufficient in this matter since combined treatment application requires hardware and experience. There are centers reporting that the commencement of empirical treatment without waiting for the factor to be detected in risky patients with findings of respiratory tract infection or in patients that provide protection with oseltamivir in the influenza season $(3,21)$.

Immunization is also an option in influenza infections alongside antiviral treatment. Infectious Diseases Society of America recommends the intramuscular administration of inactive influenza virus immunization to all immunosuppressed patients older than 6-months except for patients receiving intensive chemotherapy and the ones that have received anti-B cell anti- body in the last six months (for the possibility of not obtaining response to immunization) and to related healthcare workers. Active influenza immunization should not be administered to these patients and their family members $(1,33)$. It is recommended in the prevention of the disease that particularly the patient and family members be informed and immunized, be more attentive in periods of epidemic, and be aloof from infected individuals and crowded environments.

\section{Rhinovirus}

While detection rates of rhinoviruses with traditional diagnostic methods is low, detection rate $(28.1 \%-58 \%)$ has increased in recent years with the use of multiplex molecular methods $(2,6,34)$. Rhinovirus infections that heal on its own in a short time in healthy individuals can last longer in immunosuppressed patients and lead to significant complications. Furthermore, the virus can reproduce for a long time in the respiratory tract in asymptomatic patients and prolonged scattering can be observed. A study has reported that rhinovirus positivity in HSCT patients can last 30 to 174 days. The virus can clinically affect the upper (64\%) and lower (36\%) respiratory tracts and recurrent infections can be seen due to different genotypes (rhinovirus A, $B$ and C) (17,34). Studies regarding rhinovirus infections in HSCT patients are limited, and hence, new studies are required in order to understand the significance of the infection.

\section{Adenoviruses}

Adenovirus-related respiratory tract infections have been reported at a rate of $7 \%-13.5 \%$ in HSCT patients $(2,4)$. Adenovirus-induced infections are seen throughout the year and can progress with high mortality rates (30\%-50\%). Adenoviruses can cause gastroenteritis, hepatitis, nephritis, and hemorrhagic cystitis by affecting other organs except from the respiratory tract $(4,12,13,35)$. Another important aspect is that similar to rhinoviruses, adenoviruses can also stay in the respiratory tract of HSCT patients a long time and be detected even in periods when there is no clinical finding. Adenovirus-induced infections can develop due to the re-activation of the virus or through transmission of a new virus. After HSCT, regular follow-up of adenovirus viremia is suggested in pediatric cases $(4,12)$.

There is no specific drug recommended for treatment. As regards patient's condition, apart from supportive care, it is vital to avoid immunosuppressant treatments. Even though cidofovir, prohibitor of virus DNA polymerase, has been found useful in treatment, its use is limited due to significant unwanted effects $(4,12,21)$.

\section{Much Rarely Seen Viruses}

With the introduction of multiplex molecular methods in recent years, new VRTI factors like coronaviruses (2\%-11.2\%) and metapneumoviruses (1\%-1.4\%) have been reported in low ra- 
tes $(2,4,11)$. Data regarding the infections these viruses, whose infections cannot be clinically distinguished from other viruses, cause in HSCT pediatric patients is limited.

\section{Protection and Prevention}

Owing to the fact that there is no absolute finding regarding the efficiency of antiviral drugs in VRTI treatment and the high cost of treatment, the most appropriate course is the prevention of the infection. The most important step of treatment success and the prevention of significant infections is minimizing immunosuppression as possible (19). There are studies reporting that scanning patients in terms of viruses before HSCT is useful and that viruses can be detected by nucleic acid tests before the commencement of symptoms of respiratory tract infection $(12,25)$. While isolation measures are taken in HSCT patients, high virus load, prolonged virus scatter, infection related to health care and high mortality rate should be taken into consideration $(2,3,17,21,25,32)$. Tight measures including single rooms with air filtration, hand washing before and after contact, preventing direct contact of family members and healthcare workers that show symptoms of respiratory tract infection can be of use in preventing the disease and hospital contamination. It is extremely important for patients in risk groups and healthcare workers to follow common measures such as contact isolation, hand cleaning, and use of protective mask and gloves. It is recommended to closely and regularly monitor risky patients in terms of infection symptoms, especially in periods of outbreaks (1-3).

\section{Conclusion}

VRTI seen after HSCT that is implemented successfully in the treatment of many diseases remains a serious problem. Quick and correct diagnosis of viral respiratory tract infections has been ensured with the help of molecular methods in recent years. However, data regarding linical aspects, characteristics and treatment methods of VRTI in this special patient group is limited at the present time. Moreover, there is need for new studies in order to understand the association of virus or viruses detected by molecular methods with clinical pictures in symptomatic and asymptomatic periods regarding respiratory tracts.

Peer-review: Externally peer-reviewed.

Author Contributions: Concept - IS, DÇ; Design - IS, DÇ; Supervision - DÇ; Literature Review - IS; Writing - IS; Critical Review - DÇ

Conflict of Interest: No conflict of interest was declared by the authors.

Financial Disclosure: The authors declared that this study has received no financial support.

\section{References}

1. Tomblyn M, Chiller T, Einsele $H$, et al. Guidelines for preventing infectious complications among hematopoietic cell transplantation recipients: a global perspective. Biol Blood Marrow Transplant 2009;15:1143-238. [CrossRef]

2. Choi JH, Hwa Choi E, Jin Kang H, et al. Respiratory viral infections after hematopoietic stem cell transplantation in children. J Korean Med Sci 2013;28:36-41.[CrossRef]

3. Luján-Zilbermann J, Benaim E, Tong X, et al. Respiratory virus infections in pediatric hematopoietic stem cell transplantation. Clin Infect Dis 2001;33:962-8. [CrossRef]

4. HutspardolS, Essa M, Richardson S, et al. Significant transplantation-related mortality from respiratory virus infections within the first one hundred days in children after hematopoietic stem cell transplantation. Biol Blood Marrow Transplant 2015;21:1802-7. [CrossRef]

5. Gueller S, Duenzinger U, Wolf T, et al. Successful systemic high-dose ribavirin treatment of respiratory syncytial virus-induced infections occurring preengraftment in allogeneic hematopoietic stem cell transplant recipients. Transpl Infect Dis 2013;15:435-40. [CrossRef]

6. Piralla A, Zecca M, Comoli P, Girello A, Maccario R, Baldanti F. Persistent rhinovirus infection in pediatric hematopoietic stem cell transplant recipients with impaired cellular immunity. J Clin Virol 2015;67:38-42. [CrossRef]

7. Dolowy WC, Muldoon RL. Studies of germfree animals. I. Response of mice to infection with influenza A virus. Proc Soc Exp Biol Med 1964;116:365-71.

8. Ichinohe $T$, Pang $I K$, Kumamoto $Y$, et al. Microbiota regulates immune defense against respiratory tract influenza A virus infection. Proc Natl Acad Sci 2011;108:5354-9. [CrossRef]

9. Abt MC, Osborne $L C$, Monticelli $L A$, et al. Commensal bacteria calibrate the activation threshold of innate antiviral immunity. Immunity 2012;37:15870. [CrossRef]

10. Robinson CM, Pfeiffer JK. Viruses and the microbiota. Ann Rev Virol 2014;1:55-69. [CrossRef]

11. Fisher BT, Danziger-Isakov L, Englund J, et al. Epidemiology of respiratory viral infections in pediatric solid organ transplant or hematopoietic stem cell transplant recipients. San Diego: ID Week, 7-11 October 2015:(poster no) 1195 .

12. Bredius RG, Templeton $K E$, Scheltinga $S A$, Claas EC, Kroes AC, Vossen JM. Prospective study of respiratory viral infections in pediatric hemopoietic stem cell transplantation patients. Pediatr Infect Dis J 2004;23:518-22. [CrossRef]

13. Lo MS, Lee GM, Gunawardane N, Burchett SK, Lachenauer CS, Lehmann LE. The impact of RSV, adenovirus, influenza, and parainfluenza infection in pediatric patients receiving stem cell transplant, solid organ transplant, or cancer chemotherapy. Pediatr Transplant 2013;17:133-43. [CrossRef]

14. Rodriguez-Martinez CE, Rodriguez DA, Nino G. Respiratory syncytial virus, adenoviruses, and mixed acute lower respiratory infections in children in a developing country. J Med Virol 2015;87:774-81. [CrossRef]

15. Waghmare A, Campbell AP, Xie H, et al. Respiratory syncytial virus lower respiratory disease in hematopoietic cell transplant recipients: viral RNA detection in blood, antiviral treatment, and clinical outcomes. Clin Infect Dis 2013;57:1731-41.

16. Saglik I, Mutlu $D$, Ongut $G$, et al. Investigation of adenoviruses in children with lower respiratory tract infections. Mikrobiyol Bul 2013;47:282-94. [CrossRef]

17. Srinivasan A, Flynn $P, G u Z$, et al. Detection of respiratory viruses in asymptomatic children undergoing allogeneic hematopoietic cell transplantation. Pediatr Blood Cancer 2013;60:149-51. [CrossRef] 
18. Bakerman P, Balasuriya L, Fried O, Tellez D, Garcia-Filion P, Dalton H. Direct fluorescent-antibody testing followed by culture for diagnosis of $2009 \mathrm{H} 1 \mathrm{~N} 1$ influenza A. J Clin Microbiol 2011;49:3673-4. [CrossRef]

19. Sağlık $I$, Mutlu $D$, Öngüt $G$ ve ark. Çocuklarda respiratuvar sinsityal virüs (RSV) enfeksiyonlarının tanısında hücre kültürü ve direkt floresan antikor testi yöntemlerinin karşılaştırılması. Türk Mikrobiyol Cem Derg 2015;45:229. [CrossRef]

20. Hacımustafaoğlu M, Celebi S, Bozdemir SE, et al. RSV frequency in children below 2 years hospitalized for lower respiratory tract infections. Turk $J$ Pediatr 2013;55:130-9.

21. Ison MG. Respiratory viral infections in transplant recipients. Antivir Ther 2007;12:627-38. [CrossRef]

22. Bonner AB, Monroe KB, Talley LI, Klasner A, Kimberlin DW. Impact of the rapid diagnosis of influenza on physician decision-making and patient management in the pediatric emergency department: results of a randomized, prospective, controlled trial. Pediatrics 2003;112:363-7. [CrossRef]

23. Poritz $M A$, Blaschke $A J$, Byington $C L$, et al. FilmArray, an automated nested multiplex PCR system for multi-pathogen detection: development and application to respiratory tract infection. PLoS One 2011;6:e26047. [CrossRef]

24. Salez $N$, Vabret $A$, Leruez-Ville $M$, et al. Evaluation of four commercial multiplex molecular tests for the diagnosis of acute respiratory infections. PLoS One 2015;10:e0130378. [CrossRef]

25. Templeton KE. Why diagnose respiratory viral infection? J Clin Virol 2007;40(Suppl 1):S2-4. [CrossRef]

26. Ciçek C, Bayram N, Anıl M, et al. Simultaneous detection of respiratory viruses and influenza $A$ virus subtypes using multiplex PCR. Mikrobiyol Bul 2014;48:652-60. [CrossRef]
27. Sung L, Todd A Alonzo, Robert B Gerbing, et al. Respiratory syncytial virus infections in children with acute myeloid leukemia: a report from the Children's Oncology Group. Pediatr Blood Cancer 2008;51:784-6. [CrossRef]

28. Molinos-Quintana A, Pérez-de Soto C, Gómez-Rosa M, et al. Intravenous ribavirin for respiratory syncytial viral infections in pediatric hematopoietic SCT recipients. Bone Marrow Transplant 2013;48:265-8. [CrossRef]

29. Eisenhut M. Extrapulmonar manifestations of severe respiratory syncytial virus infection-a systematic review. Crit Care 2006;10:R107. [CrossRef]

30. Shachor-Meyouhas Y,Zaidman I, Kra-OzZ, Arad-Cohen N, Kaais I. Detection, control, and management of a respiratory syncytial virus outbreak in a pediatric hematology-oncology department. I Pediatr Hematol Oncol 2013;35:124-8. [CrossRef]

31. Chemaly RF, Shah DP, Boeckh MJ. Management of respiratory viral infections in hematopoietic cell transplant recipients and patients with hematologic malignancies. Clin Infect Dis 2014;59:S344-51. [CrossRef]

32. Srinivasan A, Wang C, Yang J, Shenep JL, Leung WH, Hayden RT. Symptomatic parainfluenza virus infections in children undergoing hematopoietic stem cell transplantation. Biol Blood Marrow Transplant 2011;17:1520-7. [CrossRef]

33. Rubin LG, Levin MJ, Ljungman P, et al. 2013 IDSA clinical practice guideline for vaccination of the immunocompromised host. Clin Infect Dis 2014;58:309-18. [CrossRef]

34. Loria C, Domm JA, Halasa NB, et al. Human rhinovirus Cinfections in pediatric hematology and oncology patients. Pediatr Transplant 2015;19:94-100. [CrossRef]

35. Ison MG. Adenovirus infections in transplant recipients. Clin Infect Dis 2006;43:331-9. [CrossRef] 